\title{
DETEKSI DINI ANEMIA SEBAGAI UPAYA MENCIPTAKAN GENERASI SEHAT REPRODUKSI PADA REMAJA PUTRI DI SMK MATHLA'UL ANWAR PAKIS JAYA KABUPATEN KARAWANG 2018
}

OLEH:

\author{
Riska Setiawati, Oon Sopiah, Astri Nurdiana
}

riska.setiawati@fikes.unsika.ac.id, oon.sopiah@fkes.unsika.ac.id astri.nurdiana@fikes.unsika.ac.id

\section{A. DASAR PEMIKIRAN}

Pada umumnya anemia lebih sering terjadi pada wanita dan remaja putri dibandingkan dengan pria. Yang sangat disayangkan adalah kebanyakan penderita tidak tahu atu tidak menyadarinya. Remaja putri menderita anemia hal ini disebabkan oleh berbagai faktor antara lain karena masa remaja adalah masa pertumbuhann yang membutuhkan zat gizi lebih tinggi termasuk zat besi. Tujuan pengabdian ini adalah untuk melakukan deteksi awal anemia pada remaja putri sebagai upaya menciptakan reproduksi yang sehat. Selain itu juga untuk meningkatkan ilmu pengetahuan dalam pencegahan terjadinya anemia, karena remaja putri yang tidak anemia dapat menghasilkan reproduksi yang sehat.

\section{B. TUJUAN}

\section{Tujuan Umum}

Tujuan pengabdian ini adalah untuk melakukan deteksi awal anemia pada remaja putri sebagai upaya menciptakan reproduksi yang sehat di SMK Mathla'ul Anwar Pakis Jaya Kabupaten Karawang 2018

2. Tujuan Khusus

a. Untuk melakukan deteksi dini anemia pada remaja putri SMK Mathla'ul Anwar Pakis Jaya

b. Memberikan pendidikan kesehatan pada remaja putri tentang anemia SMK Mathla'ul

Anwar Pakis Jaya

\section{BENTUK KEGIATAN}

Adapun bentuk kegiatan pengabdian pada masyarakat ini yaitu dalam bentuk pemeriksaan secara langsung dan mengamati nilai yang dihasilkan oleh sebuah alat untuk memeriksa haemoglobin serta melakukan pendidikan kesehatan setelah diperoleh hasil.

\section{SASARAN}

Adapun sasaran dari pengabdian masyarakat ini adalah siswa perempuan kelas X,XI dan XII SMK Mathla'ul Anwar Pakis Jaya.

\section{E. TEMPAT DAN WAKTU}

Pelaksanaan kegiatan
pengabdian masyarakat ini
dilaksanakan di SMK Mathla'ul Anwar
Kecamatan Pakis Jaya Kabupaten
Karawang dilaksankan selama dua hari
pada tanggal 04 Agustus dan 11
Agustus 2018, dimulai pada pukul
16.00 s.d 18.00.

\section{F. HASIL KEGIATAN}

Hasil dari kegiatan pengabdian masyarakat ini yaitu siswa putri yang telah mengikuti kegiatan ini dapat mengetahui keadaan kesehatan dirinya 
dalam hal anemia serta dapat menambah pengetahuan tentang anemia sehingga mereka dapat mempersiapkan untuk saat ini dan kedepanya tentang dampak dari anemia bila dialami oleh seorang perempuan. Hasil pemeriksaan menunjukkan adanya 15 siswa putri yang mengalami anemia dengan haemoglobin kurang dari angka 12 gram/dL

Seorang guru SMK Mathla'ul Anwar merasakan hasil dari kegiatan pengabdian ini yaitu terutama bila ada siswa putri yang mengalami anemia akan lebih memperhatikan bila siswa putri tersebut mengikuti kegiatan ekstra kulikuler, kemudian karena kegiatan pengabdian masyarakat ini bertepatan dengan akan dilaksakannya pengibaran bendera saat acara kemerdekaan dan siswa putri berkesempatan mengikuti kegiatan tersebut maka kegiatan pengabdian masyarakat ini menjadi dasar salah satunya dalam mendeteksi keadaan kesehatan siswa putri SMK Mathla'ul Anwar.

Mahasiswa dapat mengaplikasikan kegiatan pendidikan kesehatan yang merupakan suatu rangkaian praktikum mata kuliah yang dilaksanakan di kampus, akan tetapi saat ini mereka melaksanakan langsung kepada siswa putri dengan kooperatuf.

Kegiatan ini merupakan bentuk pengabdian masyarakat bagi dosen Prodi Kebidanan Unsika melalui deteksi dini anemia dan pendidikan kesehatan dalam upaya membentuk generasi sehat reproduksi.

\section{G. DAFTAR PUSTAKA}

1. Almaitzer, S. 2009. Prinsip Dasar Ilmu Gizi. Gramedia Pustaka Utama : Jakarta.

2. Asrinah, dkk. 2010. Asuhan Kebidanan Masa Kehamilan.Graha Ilmu : Yogyakarta
3. Aulia, 2012. Serangan PenyakitPenyakit Khas Wanita Paling Sering terjadi. Buku Biru : Yogyakarta

4. Depkes R.I. 2003. Anemia Gizi dan Tablet Tambah Darah (TTD) untuk wanita Usia Subur. Jakarta : Departemen Kesehatan

5. Handayani dan Haribowo, 2008. Asuhan Keperawatan pada Klien dengan Gangguan Sistem Hematologi. Salemba Medika : Jakarta.

6. Isniati. 2007. Wanita lebih berisiko Terkena Anemia. http://www.pemkomedan.go,id/wan ita-lebih-berisiko-terkena-anemiahtml.

7. Sediaoetama, AD 2003. Ilmu Gizi Untuk Mahasiswa Dan Profesi Di Indonesia Jilid I,II,III. Penerbit Dian Rkayat :Jakarta.

8. Survei Kesehatan Rumah Tangga (SKRT) Pedoman Penanggulangan Anemia Gizi Untuk Remaja Putri dan Wanita Usia Subur.

9. Tarwoto, Ns. Dkk. 2009. Kesehatan Remaja Problem dan Solusinya. Jakarta : Salemba Medika

10. Idyastuti, et al. 2009. Kesehaan Reproduksi. Yogyakarta : Fitramaya

11. Yusuf, Syamsu. 2011. Psikologi Perkembangan Anak dan Remaja.Bandung: PT Remaja Rosdakarya 
H. DOKUMENTASI

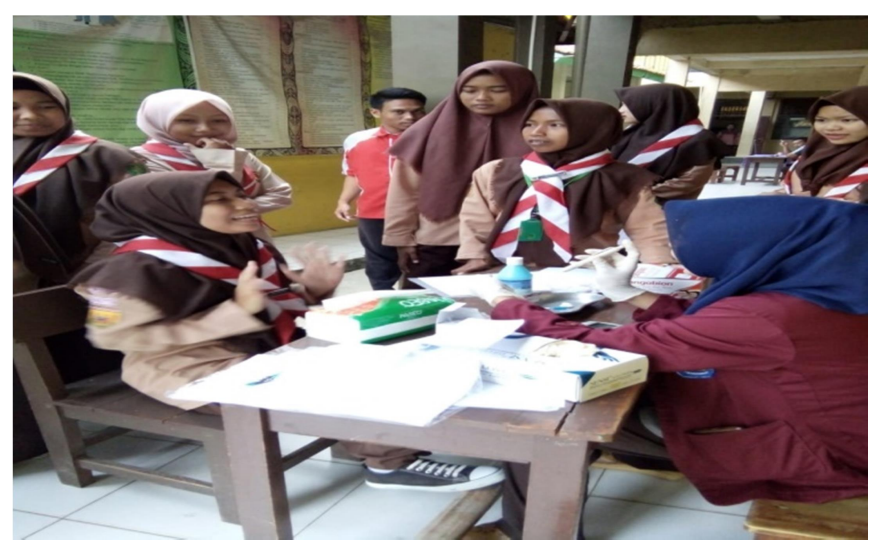

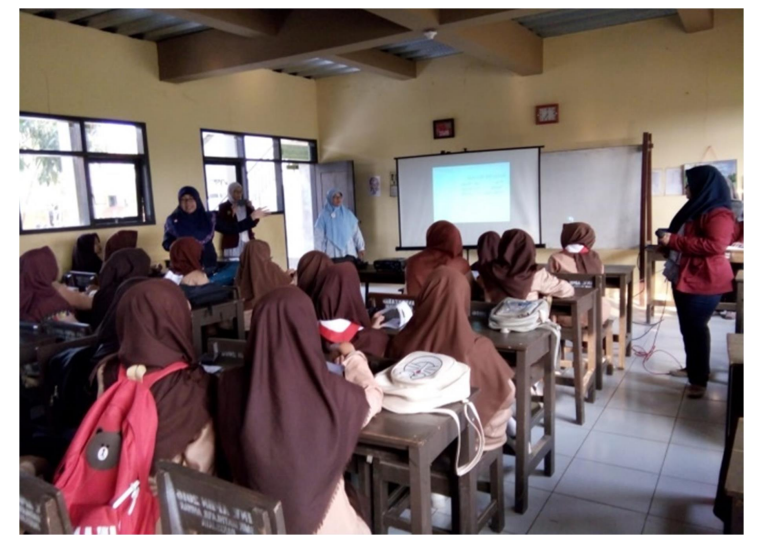

